\title{
MISTI
}

BFEC-1981-3

\section{ENVIRONMENTAL MONITORING REPORT} U.S. DEPARTMENT OF ENERGY FACILITIES

GRAND JUNCTION, COLORADO, AND MONTICELLO, UTAH

Bendix Field Engineering Corporation

Grand Junction Operations

Grand Junction, CO 81502

April 1981

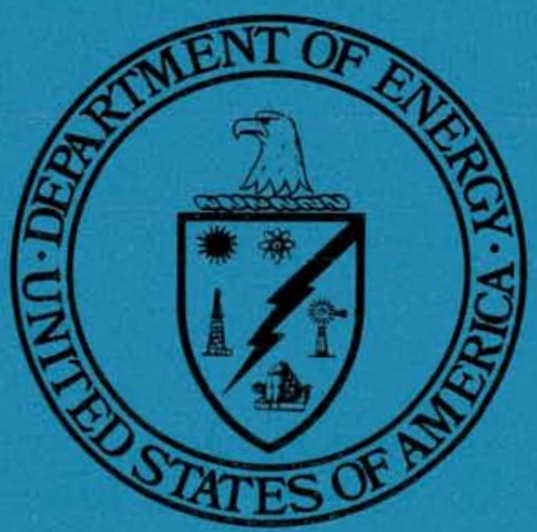




\section{DISCLAIMER}

This report was prepared as an account of work sponsored by an agency of the United States Government. Neither the United States Government nor any agency Thereof, nor any of their employees, makes any warranty, express or implied, or assumes any legal liability or responsibility for the accuracy, completeness, or usefulness of any information, apparatus, product, or process disclosed, or represents that its use would not infringe privately owned rights. Reference herein to any specific commercial product, process, or service by trade name, trademark, manufacturer, or otherwise does not necessarily constitute or imply its endorsement, recommendation, or favoring by the United States Government or any agency thereof. The views and opinions of authors expressed herein do not necessarily state or reflect those of the United States Government or any agency thereof. 


\section{DISCLAIMER}

Portions of this document may be illegible in electronic image products. Images are produced from the best available original document. 


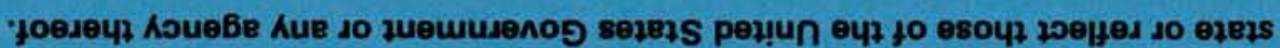

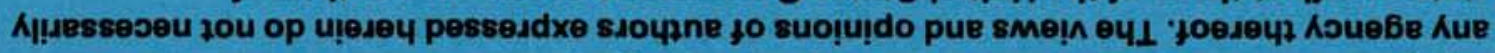

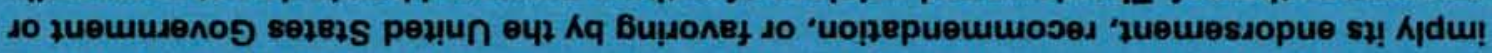

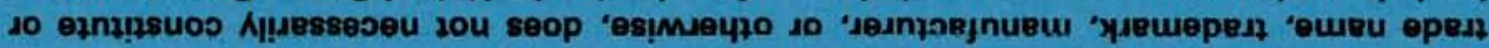

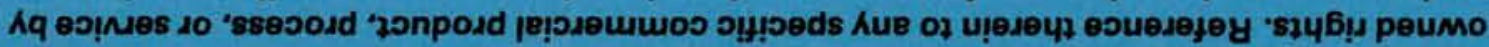

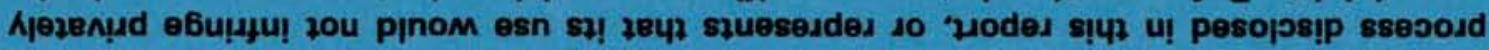

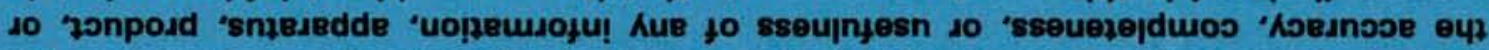

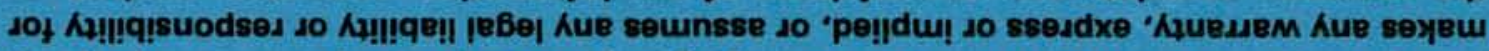

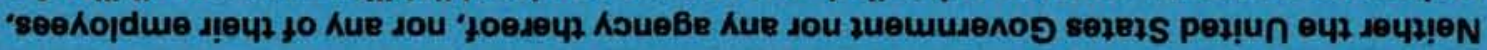


1980 ENVIRONMENTAL MONITORING REPORT U.S. DEPARTMENT OF ENERGY FACILITIES GRAND JUNCTION, COLORADO AND MONTICELLO, UTAH

BENDIX FIELD ENGINEERING CORPORATION

Grand Junction Operations

P.O. Box 1569

Grand Junction, Colorado 81502

Nic Korte

Ralph Thul

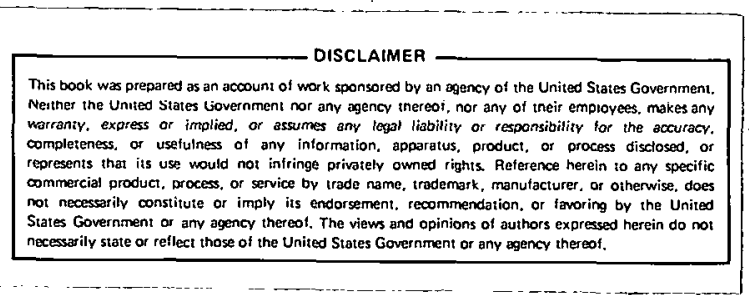

April 1981 
Grand Junction Office, DOE . . . . . . . . . . . . . . . . . . 5

Areas of concern and activities. . . . . . . . . . . . . . . . 5

I. THE GRAND JUNCTION, COLORADO, DOE FACILITY

1.0 Air quality analyses. . . . . . . . . . . . . . . . 7

1.1 Sample Plant . . . . . . . . . . . . . . . . . . 7

1.2 Analytical Laboratory. . . . . . . . . . . . . . . . 7

1.3 Emissions from combustion. . . . . . . . . . . . . . . 8

1.3.1 Automobiles . . . . . . . . . . . . . . . . 8

1.3.2 Central Heating Plant................... 8

1.3 .3 Other sources . . . . . . . . . . . . . . . 9

1.4 Radioactive emissions. . . . . . . . . . . . . . . . ' 9

2.0 Water quality analyses . . . . . . . . . . . . . . . 10

2.1 Waste water discharges and treatment . . . . . . . . . . 10

2.2 Surface water. . . . . . . . . . . . . . . . . 14

2.3 Ground water ..................... 17

3.0 Process waste liquids. . . . . . . . . . . . . . . . . 22

3.1 Analytical Laboratory. . . . . . . . . . . . . . . 22

3.2 Photographic Laboratory. . . . . . . . . . . . . . . . 22

4.0 Solid waste. . . . . . . . . . . . . . . . . . . . 22

II. THE MONTICELLO, UTAH, INACTIVE URANIUM MILL SITE

1.0 Site environment . . . . . . . . . . . . . . . . . . 25

1.1 Facility description and history . . . . . . . . . . . . 25

1.2 Site geology . . . . . . . . . . . . . . . . . 25

1.3 Site hydrology . . . . . . . . . . . . . . . . . 26

1.4 Previous environmental degradation . . . . . . . . . . . . . 26

1.5 Site reclamation . . . . . . . . . . . . . . . . 29

1.6 . Existing site conditions . . . . . . . . . . . . . . . . 29

2.0 Current environmental status . . . . . . . . . . . . . . 31

2.1 Air quality analyses . . . . . . . . . . . . . . . 31

2.2 Water quality analyses . . . . . . . . . . . . . . 31

2.2.1 Surface water ..................... 32

2.2 .2 Ground water. . . . . . . . . . . . . . . 32

2.3 Wind and water erosion . . . . . . . . . . . . . . . . 34

2.4 Improvement programs . . . . . . . . . . . . . . . 38 


\section{ILLUSTRATIONS}

PAGE

Figure 1. Drainage, sampling wells, tailings area - Grand Junction, Colorado. . . . . . . . . . . . . . . . . .

Figure 2. Sampling locations and burial areas for radioactively contaminated materials. . . . . . . . . . . . 27

Table 1. Radon flux measurements, Grand Junction facility. . . . . 9

Table 2. Sampling sites, Grand Junction facility... . . . . . . . . 15

Table 3. Analyses of water samples, Gunnison River . . . . . . . . . 16

Table 4. Analyses of water samples from waste sites and test wells, Grand Junction facility................. 18

Table 5. Analyses of sediments from waste sites and test wells, Grand Junction facility . . . . . . . . . . . . . .

Table 6. Analyses of sediments, Gunnison River, Grand Junction faclitty. . . . . . . . . . . . . . . . .

Table 7. Photochemicals used in Grand Junction facility Photographic Laboratory. . . . . . . . . . . . . . . . .

Table 8. Analyses of surface water samples collected at the Monticello site during 1980 . . . . . . . . . . .

Table 9. Analyses of well water samples collected at the Monticello site during 1980 . . . . . . . . . .

Table 10. Analyses of well water samples. collected near the Monticello site during 1980 . . . . . . . . . . . . 
The Grand Junction Office (GJO), U.S. Department of Energy (DOE), develops and administers programs for evaluating domestic uranium resources and the production capability of industry; for developing resource planning information for DOE; and for advancing geologic and geophysical exploration concepts and techniques. In addition, GJO administers the leasing of mineral lands under DOE control, and carries out activities relating to the environmental aspects of uranium mining and milling, including remedial. programs. The office is staffed by administrative and technical program-management personnel. Bendix Field Engineering Corporation (Bendix) is the DOE operating contractor at the Grand Junction, Colorado, Government-owned/contractor-operated (GOCO) facility. The technical staffs of both GJO and Bendix are primarily geoscience-oriented.

The DOE Grand Junction facility is located on a 48.6-acre tract along the Gunnison River, south of the city of Grand Junction. Forty-three buildings house the many functions of the organization.

\section{AREAS OF CONCERN AND ACTIVITIES}

The effect the Grand Junction, Colorado and Monticello, Utah facilities have on the environment is reflected by the analyses of air, water, and sediment samples. The off-site water and sediment samples were taken to determine what effect the tailings and contaminated equipment burled on the sites may have on the air, water, and adjacent properties. 
THIS PAGE

\section{WAS INTENTIONALLY LEFT BLANK}


1.0 Air Quality Analyses

1.1 Sample Plant

During 1980, the Sample Plant prepared approximately 1000 samples per month. The majority of these samples were not uranium ores but exploration samples of low radioactivity. Thus, the principal environmental problem is dust generated from the grinding and crushing.

The low radioactivity was demonstrated by air sampling performed in the Sample Plant during July 1980. The sampling was done while ore samples were being prepared. The most concentrated sample contained $0.0046 \mathrm{mg} / \mathrm{m}^{3}$ of uranium. The relevant American Conference of Government and Industrial Hygienists (ACGIH) standards are $0.2 \mathrm{mg} / \mathrm{m}^{3}$ for uranium. Occasionally, very high grade uranium or thorium ore (5-10 percent $\mathrm{U}_{3} \mathrm{O}_{8}$ or $\mathrm{ThO}_{2}$ ) is handled in the preparation of calibration models. This operation could produce dust which exceeds the uranium-in-dust standard.

A baghouse is used for collecting dust generated by the crushing and pulverizing operations. Up to two 55-gallon drums of waste material are collected in a year. These drums are stored above ground in the buried tailings area. Considering the low levels of toxic materials in the dust and the efficiency of the baghouse (approximately 99 percent), the potential for air pollution from the Sample Plant is slight.

\subsection{Analytical Laboratory}

The Analytical Laboratory performs a wide variety of chemical and physical tests, often employing mineral acids for the digestion of rock samples. These digestions are performed in any one of ten fume hoods. Combinations of hydrofluoric, sulfuric, nitric, hydrochloric, and perchloric acids are used in these digestions; all of these acids are highly toxic. 
During 1980, new fume hoods with scrubbers were installed. Ventilation within the building is excellent. However, preliminary tests of the scrubbers indicate that perchloric acid is being scrubbed poorly. Visible emissions during perchloric acid digestions fail the State of Colorado opacity standard (Regulation $1 \mathrm{~A}-1$ ). Personnel at this facility are currently working on the problem.

\subsection{Emissions from Combustion}

\subsubsection{Automobiles}

The activities of concern are the automoblles that deliver the population of approximately 600 persons to the facillty and the daily automobile activity within the facility. The principal air pollutants emitted by automotive sources are carbon monoxide, nitrogen oxides, and unburned hydrocarbons. The Ambient Air Quality Standards of the U.S. Environmental Protection Agency (EPA) for these pollutants are as follows:

$\begin{array}{lrc}\text { Carbon monoxide } & 9 \mathrm{ppm} & 8 \mathrm{hr} \text {. avg. } \\ & 35 \mathrm{ppm} & 1 \mathrm{hr} \text {. avg. } \\ \text { Nitrogen oxides } & 0.05 \mathrm{p} \mathrm{pm} & \text { annual avg. } \\ \text { Hydrocarbons } & 0.24 \mathrm{ppm} & 3 \mathrm{hr} \text {. avg. }\end{array}$

Neither of the automotive activities associated with the facility, even during periods of construction and enhanced activity, would cause these levels of air pollutants to be exceeded.

\subsubsection{Central Heating Plant}

The Heating Plant includes two main natural-gas-fired steam bollers: a Babcock and Wilcox boiler rated at $17,250 \mathrm{lb} / \mathrm{hr}$ and a Keeler boiler rated at $8400 \mathrm{lb} / \mathrm{hr}$ ( $264 \mathrm{HP}$ ). One small natural-gas-fired package boiler is also available for use when heating requirements are low. When both the large boilers are operating at full load, they will generate approximately $35 \mathrm{x}$ $10^{6} \mathrm{BTU}$ per hour, and will produce about $0.21 \mathrm{~b} / \mathrm{hr}(0.03 \mathrm{~g} / \mathrm{sec})$ of nitrogen oxides $\left(\mathrm{NO}_{\mathrm{x}}\right)$ in the stack gas. This level of $\mathrm{NO}_{\mathrm{x}}$ in the stack gas will not cause a significant increase of $\mathrm{NO}_{\mathrm{x}}$ concentrations in the ambient air beyond a radius of 5 meters from the stack except during air inversions. The Central Heating Plant emits no other air pollutants in significant quantities. 


\section{3 .3 Other Sources}

Other minor combustion points at the facility (one individual building boiler, hot water heaters, etc.) produce negligible quantities of air pollutants.

\subsection{Radioactive Emissions}

Current operations at the Grand Junction facility do not emit significant quantities of radiation into the atmosphere. Both the Sample Plant and the Analytical Laboratory emit less than 1 microcurie of radon per year.

The only appreciable discharge of radiation to the atmosphere comes from the buried tailings area. Thirty-thousand tons of uranium mill tailings, contaminated equipment, and ore samples have been buried just north of the sewage lagoon. No activities are conducted within the tailings burial site and the area is fenced and posted. Radon flux measurements taken during May of 1979 are shown in Table 1.

TABLE 1. RADON FLUX MEASUREMENTS, GRAND JUNCTION FACILITY

\begin{tabular}{|c|c|c|}
\hline CANISTER & LOCATION & $\begin{array}{c}\text { FLUX } \\
\mathrm{pCI} / \mathrm{m}^{2}-\mathrm{S} \\
\end{array}$ \\
\hline A & $E$ of tallings, $30 \mathrm{ft} W$ of road & $50.2 \pm 3.2$ \\
\hline B & $\begin{array}{l}\text { E edge of tallings, on berm. } 50 \mathrm{ft} \\
W \text { of road }\end{array}$ & $106.6 \pm 4.2$ \\
\hline C & Center of $1962-1970$ burial area & $25.3 \pm 2.8$ \\
\hline $\mathrm{D}$ & "R"pit zone & $10.3 \pm 2.4$ \\
\hline E & Airport pad cleanup area & $3.1 \pm 1.4$ \\
\hline F & Lignite burial area & $47.1 \pm 3.4$ \\
\hline G & Among buried barrels, $10 \mathrm{ft} N$ of $D$ & $4.6 \pm 1.4$ \\
\hline - $\mathrm{H}$ & On berm., center of tallings area & $20.7 \pm 2.7$ \\
\hline I & $\mathrm{NE}$ quadrant of tailings area & $70.1 \pm 4.1$ \\
\hline $\mathrm{J}$ & NW quadrant of taflings area & $52.0 \pm 3.6$ \\
\hline $\mathrm{K}$ & SE quadrant of tailings area & $45.2 \pm 3.5$ \\
\hline L & SW quadrant of tailings area & $64.0 \pm 4.0$ \\
\hline
\end{tabular}

EPA proposed standard for inactive uranium mill tailings is 2.0 . 


\subsection{Water Quality Analyses}

2.1 Waste Water Discharges and Treatment

All waste waters from buildings at the Grand Junction facility are passed through septic tanks before discharge to the south pond. (sewage lagoon) or north pond (ground-water pond) (see Figure 1). There are presently 24 septic tanks in active service, distributed as follows:

Building

1

$2,22,49$

6

7,47

$7 \mathrm{~A}$

8

938,45

11

12

$12 \mathrm{~A}$

18

19

20

22

26,48

28

30

$31 \mathrm{~A}$

32

46

50
Function

Central Heating Plant

offices

Printing and duplication

offices

Sampling Plant

offices

offices

South Gate House

offices

offices

Library, offices, Credit Union

North Gate House

Analytical Laboratory

offices

offices

Shop bullding

Laboratory offices

offices

Workshop

Cafeteria

offices
Septic Tanks

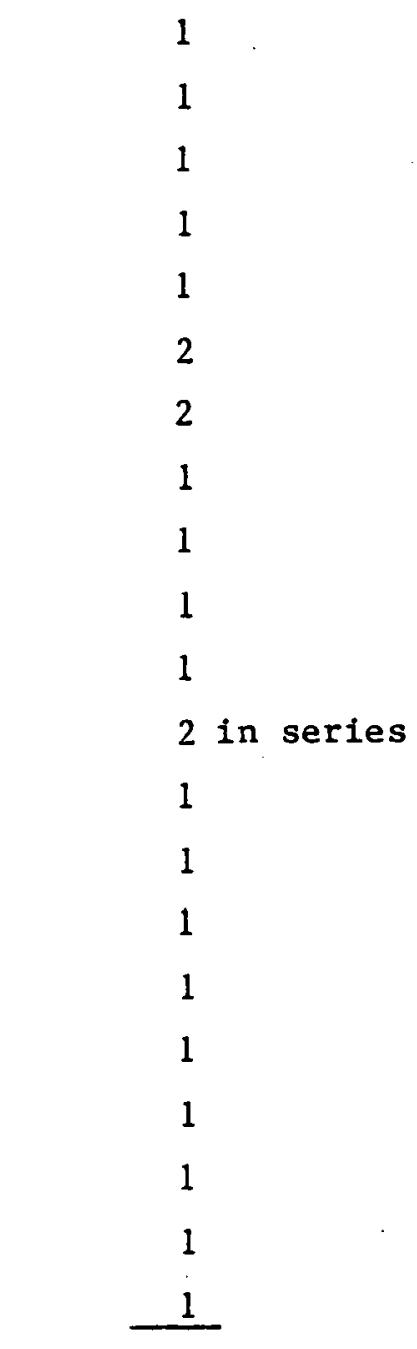

Total 24

There are two additional septic tanks in the storage areas that include Buildings 33 and 35, but these septic tanks receive no loading at the present time. All septic tanks overflow to the sewage treatment lagoon except those serving Buildings $7,7 \mathrm{~A}, 11,18,19$, and 47 . These septic tanks discharge to the following points: 

Buildings 7, 18, 19, 47

Building 7A

Building 11
Ground-water pond north of the facility

Low ground at the north end of facility (within fence)

Recelving well near the building

Approximately 25 percent of all storm water falling upon the facility is directed to the sewage lagoon by means of catch basins and drain lines at the higher elevations on the grounds. The remainder is directed to the pond at the north end of the facility by means of catch basins and drain lines. Assuming that 80 percent of sanitary waste waters from a total effective facility population of 600 persons are sent to the sewage lagoon after septic tank treatment, plus storm waters from 25 percent of the facility acreage, the total loads to the lagoon and the ground-water pond may be summarized as follows:

1) Sewage lagoon

$$
\begin{array}{ll}
\text { Sanitary sewage: } & \text { Flow }=(0.8)(\text { GPCPD })(P)=11,000 \mathrm{gal} / \text { day } \\
& \text { Load }=(0.8)(B O D P C P D)(P)=75 \mathrm{lb} \mathrm{BOD} / \text { day } \\
\text { Storm waters: } & \text { Flowa(7.5) }(A)(A A P) /(365)(12)=2,840 \mathrm{gal} / \text { day }
\end{array}
$$

2) Ground-water pond

$\begin{array}{ll}\text { Sanitary sewage: } & \text { Flow }=(0.2)(\text { GPCPD })(P)=2,750 \mathrm{gal} / \mathrm{day} \\ & \text { Load }=(0.2)(B O D P C P D)(P)=191 \mathrm{~b} \mathrm{BOD} / \text { day } \\ \text { Storm waters : } & \text { Flow }=(7.5)(A)(A A P) /(365)(12)=700 \mathrm{gal} / \text { day }\end{array}$

Where

$$
\begin{aligned}
A & =\text { surface receiving precipitation }=200,000 \mathrm{sq} . \mathrm{ft} . \text { for } \\
\text { lagoon }, 50,000 \text { for pond } & \\
\mathrm{AAP} & =\text { average annual precipitation }=8.3 \mathrm{in} / \mathrm{yr} \\
\text { BODPCPD } & =1 \mathrm{~b} \text { BOD per capita per day }=0.17 \mathrm{1b} / \mathrm{cap} / \text { day } \\
\text { GPCPD } & =\text { gallons per capita per day }=25 \mathrm{gal} / \mathrm{cap} / \text { day } \\
P & =\text { effective facility population }=600
\end{aligned}
$$

Values for BODPCPD and GPCPD are those which are widely used in standard texts and by regulatory agencies, while the annual precipitation was taken from compilations of the American Society of Heating, Air Conditioning, and Rerrigerarion Engineers (ASHRAE). 
The sewage lagoon has a surface area of about 37,000 square feet and a design volume of about 1,070,000 gallons. Maximum depth is about 4 feet. Therefore the lagoon has an average detention time of about 70 days, and the detention time would exceed 5 days even when 1 Inch of rainfall was experienced in a single event. There are no state of Colorado standards for unaerated waste stabilization ponds, but the document entitled "Criteria Used in the Review of Waste Water Treatment Facilities" (1973) states: "It is very doubtful that unaerated waste.stabilization ponds can meet the effluent standards for discharge." The usual detention times for unaerated ponds vary from 5 to 50 days, and by this yardstick the sewage lagoon at the DOE facility is typical of usual practice. On an acreage basis, the lagoon is loaded at the rate of about $88 \mathrm{lb}$. BOD per acre per day, which is relatively high for a lagoon of such shallow depth. (Lagoons 3 to 8 feet deep are typically loaded at the rate of 20-50 1b. BOD per acre per day).

The coliform count taken November 1980 in the sewage lagoon was very high $(74,000$ counts $/ 100 \mathrm{~m} 1)$. It is 11 kely that infectious waste standards to be promulgated under the Resource Conservation and Recovery Act (RCRA) will require additional monitoring or will prohibit the use of the lagoon.

To bring the Grand Junction facility within the RCRA Standards to be promulgated, design of a sewage collection system was identified in July 1980. This system will collect all sanitary and laboratory wastes and transmit them to the City of Grand Junction sewer system for treatment. All sewage will be removed from the existing lagoon. Design will begin in March 1981, and construction is scheduled to start June 1981, with completion by March 1982.

\subsection{Surface Water}

The Grand Junction facility is adjacent to the Gunnison River. There is no point-source discharge of wastes to the river; consequently, a National Pollutant Discharge Elimination System (NPDES) permit is not needed.

Samples of river water were taken upstream and downstream from the facility twice during 1980. Sample sites are shown on Figure 1 and described in Table 2. Contamination of the river water by either radioactive wastes or sewage wastes was not evident in these samples (see Table 3). 
TABLE 2. SAMPLING SITES, GRAND JUNCTION FACILITY

(OCTOBER 9, 1980)

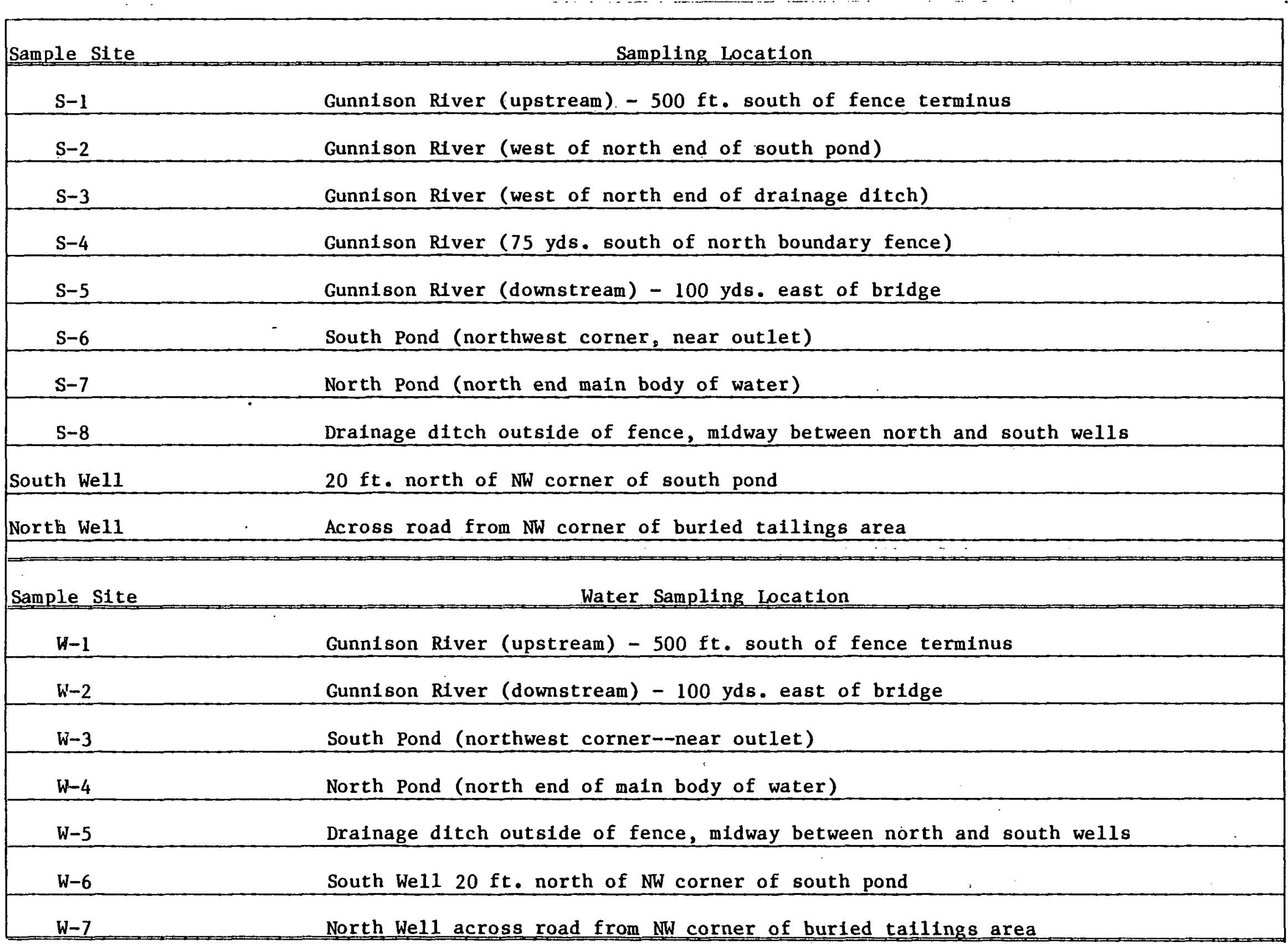


TABLE 3. ANALYSES OF WATER SAMPLES, GUNNISON RIVER, GRAND JUNCTION FACILITY (OCTOBER 9, 1980)

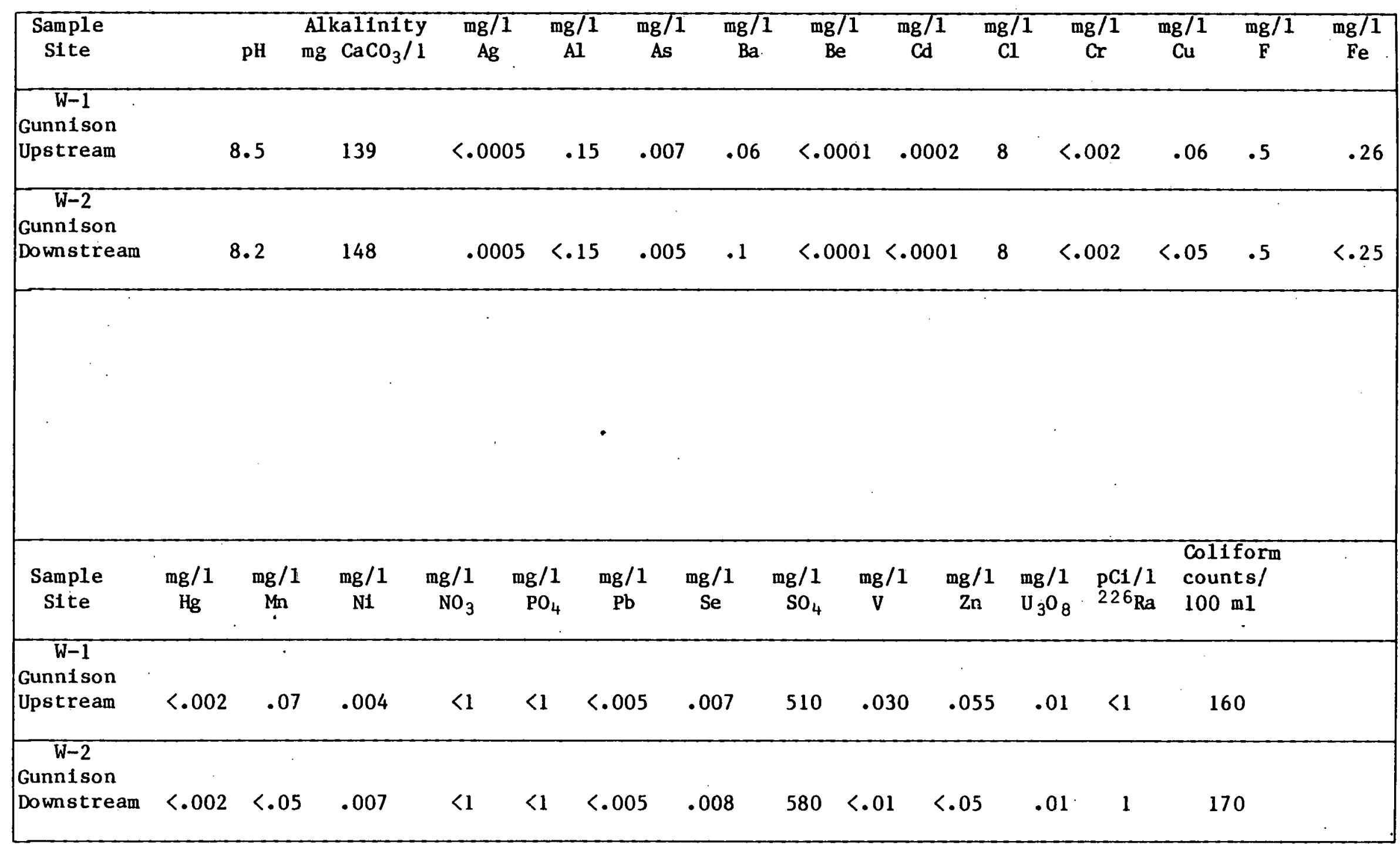




\section{$2.3^{\circ}$ Ground Water}

Ground-water contamination could occur from one of the waste lagoons or from the buried tailings site. Each of these possibilities was examined during October 1980. Sampling sites are described in Table 2 and are shown in Figure 1. Analytical data for the water and sediment samples taken during this study are displayed in Tables 4 and 5, respectively.

The sewage lagoon, or south pond, overflows into a ditch west of the burled tailings area, outside of the compound fence, and adjacent to the river dike. The water level in the ditch closely tracks the water level in the river. The coliform count is very high due to runoff from the lagoon. It is also clear that the ditch has been contaminated with tallings. This ditch could be a likely source of ground-water contamination to the river system.

The north lagoon has a much greater trace element burden than the sewage lagoon. The pond is separated from the river by approximately 100 yards. The hard-packed road bed may help contain the pond water. However, since there are no monftoring wells in the vicinity, potential ground water contamination can not be evaluated.

Two wells have been drilled to sample the effects of the buried tailings on the ground water. The south well lies near the south pond and the tailings area, and the north well lies between the drainage ditch and the tailings area. Virtually all species measured are found in concentrations much higher than the waste ponds, the river, or normal ground water (Table 5). The elements having the highest concentrations are the same ones found in the drainage ditch sediment indicating that tallings are the source. There is no doubt that the water sampled from these wells is heavily contaminated with tailings. A ground-water contamination problem exists if these wells are actually a sample of an underground aquifer.

The results from these wells clearly indicate the need for more information. If these wells are suitably constructed and sited according to the local hydrogeology, then ground water is being contaminated. If these wells are not in the proper locatinn, drillcd to the currect depth, or not adequately shielded from the tailings, then new wells are needed. Either way, some action is required. 
TABLE 4. ANALYSES OF WATER SAMPLES FROM WASTE SITES AND TEST WELLS, GRAND JUNCTION FACILITY (OCTOBER 9, 1980)

\begin{tabular}{|c|c|c|c|c|c|c|c|c|c|c|c|c|c|}
\hline $\begin{array}{l}\text { Sample } \\
\text { Site }\end{array}$ & $\overline{\mathrm{pH}}$ & $\begin{array}{l}\text { Alkalinfty } \\
\mathrm{mg} \mathrm{CaCO} / 1\end{array}$ & $\begin{array}{c}\mathrm{mg} / 1 \\
\mathrm{AG}\end{array}$ & $\begin{array}{c}\mathrm{mg} / \mathrm{l} \\
\mathrm{Al}\end{array}$ & $\begin{array}{c}\mathrm{mg} / \mathrm{l} \\
\mathrm{As}\end{array}$ & $\begin{array}{c}\mathrm{mg} / \mathrm{l} \\
\mathrm{Ba}\end{array}$ & $\underset{\mathrm{Be}}{\mathrm{mg} / 1}$ & $\underset{\mathrm{Cd}}{\mathrm{mg} / \mathrm{l}}$ & $\begin{array}{c}\mathrm{mg} / \mathrm{l} \\
\mathrm{Cl}\end{array}$ & $\begin{array}{c}\mathrm{mg} / \mathrm{l} \\
\mathrm{Cr}\end{array}$ & $\underset{\mathrm{Cu}}{\mathrm{mg} / \mathrm{l}}$ & $\begin{array}{c}\mathrm{mg} / \mathrm{l} \\
\mathrm{F}\end{array}$ & $\begin{array}{c}\mathrm{mg} / \mathrm{l} \\
\mathrm{Fe}\end{array}$ \\
\hline $\begin{array}{l}\text { W-4 } \\
\text { North } \\
\text { Pond } \\
\end{array}$ & 8.3 & 260 & .0008 & .10 & .05 & .04 & $<.001$ & .003 & 320 & .006 & .12 & 1.3 & 1.0 \\
\hline $\begin{array}{l}-3 \\
\text { South } \\
\text { Pond } \\
\end{array}$ & 7.1 & 216 & $<.0005$ & .5 & $<.005$ & .29 & $<.001$ & .002 & 80 & .011 & .01 & 2.8 & 2.4 \\
\hline $\begin{array}{l}\text { W-6 } \\
\text { South } \\
\text { We1l }\end{array}$ & 7.0 & 760 & .001 & 4.2 & .26 & .95 & .005 & $<.001$ & 160 & .036 & .003 & 1.3 & 23.0 \\
\hline $\begin{array}{l}-7 \\
\text { North } \\
\text { We11 } \\
\end{array}$ & 7.2 & 620 & .0006 & 4.1 & .93 & .98 & .005 & .002 & 80 & .010 & .006 & 1.1 & 20.0 \\
\hline $\begin{array}{l}\text { W-5 } \\
\text { Drainage } \\
\text { Ditch } \\
\end{array}$ & 7.4 & 180 & $<.0005$ & 1.1 & .05 & .31 & .001 & .002 & 90 & .008 & .064 & 1.2 & 7.3 \\
\hline $\begin{array}{l}\text { EPA } \\
\text { Standards }\end{array}$ & & & .05 & & .05 & 1.0 & & .01 & & .05 & & & \\
\hline $\begin{array}{l}\text { Sample } \\
\text { Site }\end{array}$ & $\begin{array}{c}\mathrm{mg} / 1 \\
\mathrm{Hg}\end{array}$ & $\underset{\mathrm{mg}}{\mathrm{mg} / \mathrm{l}}$ & $\underset{\mathrm{N} 1}{\mathrm{mg} / 1}$ & $\begin{array}{c}\mathrm{mg} / \mathrm{l} \\
\mathrm{NO}_{3}\end{array}$ & $\begin{array}{c}\mathrm{mg} / 1 \\
\mathrm{~Pb}\end{array}$ & $\begin{array}{c}\mathrm{mg} / 1 \\
\mathrm{PO}_{4}\end{array}$ & $\underset{\mathrm{Se}}{\mathrm{mg} / 1}$ & $\begin{array}{r}\mathrm{mg} / 1 \\
\mathrm{SO}_{4}\end{array}$ & $\mathrm{mg} / 1$ & $\underset{\mathrm{mn}}{\mathrm{mg} / 1}$ & $\begin{array}{l}\mathrm{mg} / \mathrm{I} \\
\mathrm{U}_{3} \mathrm{O}_{8}\end{array}$ & $\begin{array}{l}\mathrm{pC1/1} \\
226 \mathrm{Ra}\end{array}$ & $\begin{array}{l}\text { Coli- } \\
\text { form } \\
\text { Cts } / 100 \mathrm{ml}\end{array}$ \\
\hline $\begin{array}{l}W-4 \\
\text { North } \\
\text { Pond }\end{array}$ & $<.002$ & .98 & .130 & 2 & $<.005$ & $<1$ & $<.005$ & 4180 & .04 & .06 & .7 & 2 & 2200 \\
\hline $\begin{array}{l}\mathrm{W}-3 \\
\text { South } \\
\text { Pond } \\
\end{array}$ & $<.002$ & .22 & .018 & $<1$ & .007 & 2 & $<.005$ & 50 & .01 & .24 & .008 & 15 & 74000 \\
\hline $\begin{array}{l}\text { W-6 } \\
\text { South } \\
\text { We11 } \\
\end{array}$ & $<.002$ & 1.4 & .030 & $<1$ & $<.005$ & $<1$ & $<.005$ & 850 & .22 & .44 & 1.5 & 200 & 0 \\
\hline $\begin{array}{l}\text { W-7 } \\
\text { North } \\
\text { We11 } \\
\end{array}$ & $<.002$ & 7.4 & .032 & 1 & .011 & $<1$ & $<.005$ & 400 & 3.77 & .47 & .3 & 10 & 10 \\
\hline $\begin{array}{l}\text { W-5 } \\
\text { Drainage } \\
\text { Ditch }\end{array}$ & $<.002$ & 1.5 & .012 & 1 & .018 & $<1$ & $<.005$ & 130 & .60 & .48 & .2 & 290 & 37000 \\
\hline $\begin{array}{l}\text { EPA* } \\
\text { Standards }\end{array}$ & .002 & & & 10 & .05 & & .01 & & & & & & \\
\hline
\end{tabular}

*From "Environmental Protection Standards for Uranium Mill Tailings" 
TABLE 5. ANALYSES OF SEDIMENTS FROM WASTE SITES AND TEST WELLS, GRAND JUNCTION FACILITY (OCTOBER 9, 1980)

\begin{tabular}{|c|c|c|c|c|c|c|c|c|c|c|}
\hline $\begin{array}{l}\text { Sample } \\
\text { Site } \\
\end{array}$ & $\begin{array}{r}\mathrm{ppm} \\
\mathrm{Ag}\end{array}$ & $\begin{array}{l}\% \\
\text { Al }\end{array}$ & $\begin{array}{r}\mathrm{ppm} \\
\mathrm{As} \\
\end{array}$ & $\begin{array}{r}\mathrm{Ppm} \\
\mathrm{Ba} \\
\end{array}$ & $\begin{array}{r}\mathrm{Ppm} \\
\mathrm{Be} \\
\end{array}$ & $\begin{array}{r}\mathrm{Ppm} \\
\mathrm{Cr} \\
\end{array}$ & $\begin{array}{r}\mathrm{ppm} \\
\mathrm{Cu} \\
\end{array}$ & $\begin{array}{l}\% \\
\mathrm{Fe} \\
\end{array}$ & $\begin{array}{r}\mathrm{Ppm} \\
\mathrm{Hg} \\
\end{array}$ & $\begin{array}{r}\mathrm{PPm} \\
\mathrm{Mn} \\
\end{array}$ \\
\hline$S-7$ & & & & & & & & & & \\
\hline $\begin{array}{l}\text { North } \\
\text { Pond }\end{array}$ & 2 & 5.2 & 8 & 655 & 1 & 13 & 10 & 2.1 & $<.5$ & 445 \\
\hline $\begin{array}{l}S-5 \\
\text { South } \\
\text { Pond } \\
\end{array}$ & 7 & 4.8 & 13 & 1010 & 1 & 17 & 15 & 2.1 & $<.5$ & 350 \\
\hline $\begin{array}{l}\mathrm{S}-8 \\
\text { Drainage } \\
\text { Ditch } \\
\end{array}$ & 18 & 8.2 & 142 & 680 & 3 & 49 & 730 & 2.5 & $<.7$ & 125 \\
\hline $\begin{array}{l}\text { Sample } \\
\text { Site }\end{array}$ & $\begin{array}{r}\mathrm{ppm} \\
\mathrm{N} 1\end{array}$ & $\begin{array}{r}\mathrm{ppm} \\
\mathrm{Pb}\end{array}$ & $\begin{array}{l}\delta \\
S\end{array}$ & $\begin{array}{l}\mathrm{ppm} \\
\mathrm{Th}\end{array}$ & $\begin{array}{c}\mathrm{ppm} \\
\mathrm{V}\end{array}$ & $\begin{array}{r}\mathrm{ppm} \\
\mathrm{Zn}\end{array}$ & $\begin{array}{r}\mathrm{ppm} \\
\mathrm{U}_{3} \mathrm{O}_{8}\end{array}$ & $\begin{array}{c}\mathrm{ppm} \\
\mathrm{eU}_{3} \mathrm{O}_{8}\end{array}$ & $\begin{array}{l}\mathrm{PCI} / \mathrm{g} \\
226 \mathrm{Ra}\end{array}$ & \\
\hline $\begin{array}{l}\text { S-7 } \\
\text { North } \\
\text { Pond } \\
\end{array}$ & 10 & 15 & .48 & 9 & 90 & 57 & 18 & 6 & 2.0 & \\
\hline $\begin{array}{l}\text { S-6 } \\
\text { South } \\
\text { Pond } \\
\end{array}$ & 10 & 15 & .15 & 9 & $\begin{array}{r}70 \\
\end{array}$ & 74 & 12 & 7 & 2.2 & \\
\hline $\begin{array}{l}\mathrm{S}-8 \\
\text { Drainage } \\
\text { Ditch }\end{array}$ & 25 & 155 & .58 & 21 & 550 & 180 & 760 & 2450 & 807 & \\
\hline
\end{tabular}


Samples of river sediment were collected alongside and slightly downstream of the buried tallings area and drainage ditch to check for contamination in the river. It is likely that trace specles leached from the tailings area to the river would quickly precipitate upon contact with the oxidizing conditions in the river.

Three separate river sediment samples were collected adjacent to the burled tallings area. Analytical results on these and the upstream and downstream sediment samples are shown in Table 6 .

The highest concentrations are consistently found in the sediment samples collected adjacent to the burled tailings. The elements $\mathrm{U}, \mathrm{Al}, \mathrm{Cu}, \mathrm{Fe}, \mathrm{Mn}$, $\mathrm{Pb}, \mathrm{Ni}, \mathrm{S}, \mathrm{V}, \mathrm{Zn}, \mathrm{Cr}$, and $226_{\mathrm{Ra}}$ all show elevated concentrations compared to the upstream sample. All of these elements are also concentrated in the tailings and/or the water in the north and south test wells.

The hypothesis that the GJO facility has contaminated the river is speculative because the concentrations are only moderately elevated over the upstream and downstream sediments, most having ratios of $2: 1$ or less. Also, some of the concentrations are virtually within experimental error of the upstream sampie, and 7 of the 12 elements have abundances less than their crustal averages.

On the other hand, the results are quite consistent. Of 20 elements measured, 12 clearly contaminate the wells and 11 of these apparently contaminate the sediments. Similarly, of 18 elements 1dentified in the drainage ditch, 14 are clearly contaminants, and 10 of the 11 sediment contaminants are among this group. The exception is manganese which has undoubtedly been mobilized by the very reducing conditions prevalent in the drainage ditch. Finally, the three river sediment samples taken adjacent to the tailings always contain higher or equal oncentrations of these elements than the upstream or downstream sediments. The consistency of these results is compelling though circumstantial evidence that the source of the elements is tailings.

The sediment sampling program will be extended next summer when the water level is lower. Tallings may have been used in construction of the dike. Samples will be taken upstream of the waste sites but st111 alongside the facility to determine whether the apparent contamination of the river bed is due to leaching from tailings used in dike construction or leaching from the buried tallings area. 
TABLE 6. ANALYSES OF SEDIMENTS, GUNNISON RIVER, GRAND JUNCTION FACILITY (OCTOBER 9, 1980)

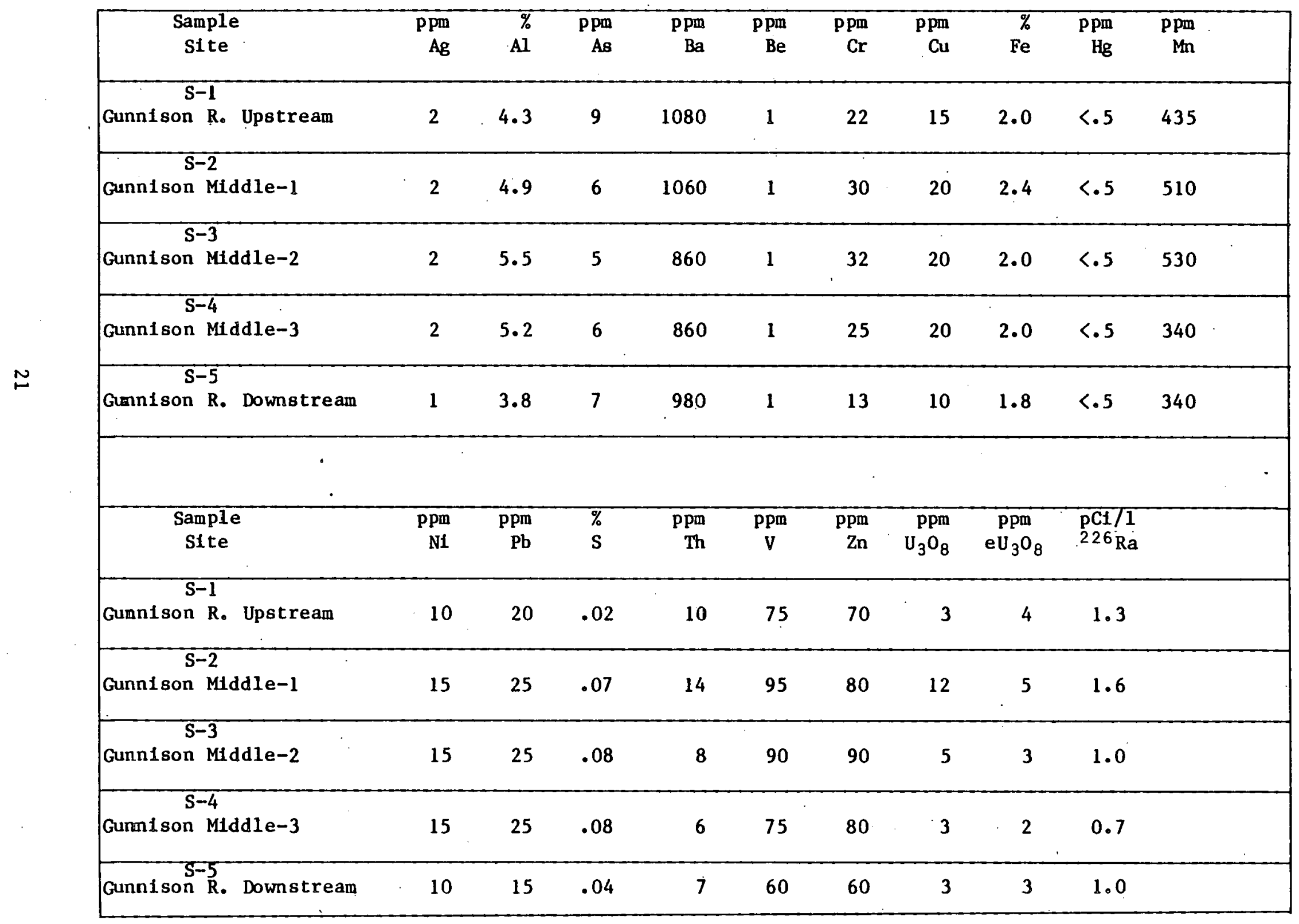




\subsection{Process Waste Liquids \\ 3.1 Analytical Laboratory}

The Analytical Laboratory discharges both acid solutions and organic wastes directly into the sewage lagoon. The total amount discharged would not be a detectable burden for a sewage system. In fact, none of the amounts of wastes discharged are considered hazardous using the criteria defined by the Resource Conservation Recovery Act (RCRA). Specifically, the maximum organic solvent discharge (mostly acetone and ethyl acetate) is estimated at 60 kilograms per month. Discharge of heavy metals such as uranium, arsenic, selenium, molybdenum, vanadium, cadmium, copper, and lead is estimated at less than 30 grams per year combined. The RCRA standard for solvents, based on their hazard as flammables, is $1000 \mathrm{~kg} / m o n t h$. The metals standards are $100 \mathrm{times}$ drinking water standards or $1 \mathrm{ppm}$ for selenium and cadmi um and $5 \mathrm{ppm}$ for lead and arsenic.

\subsection{Photographic Laboratory}

A number of chemicals are used in the routine operation of the photographic laboratory. These are listed in Table 7. None are of high toxicity and in these quantities can be safely disposed of in the sinks.

\subsection{Solid Waste}

The Resource Conservation and Recovery Act is not currently applicable to any of the activities on the facility. The buried tailings area, for example, is exempted by the Atomic Energy Act. However, it is clear that the intent of Congress is to prevent ground-water contamination. Thus, more study of the buried failings site is needed. 
TABLE 7. PHOTOCHEMICALS USED IN GRAND JUNCTION

FACILITY PHOTOGRAPHIC LABORATORY

1980

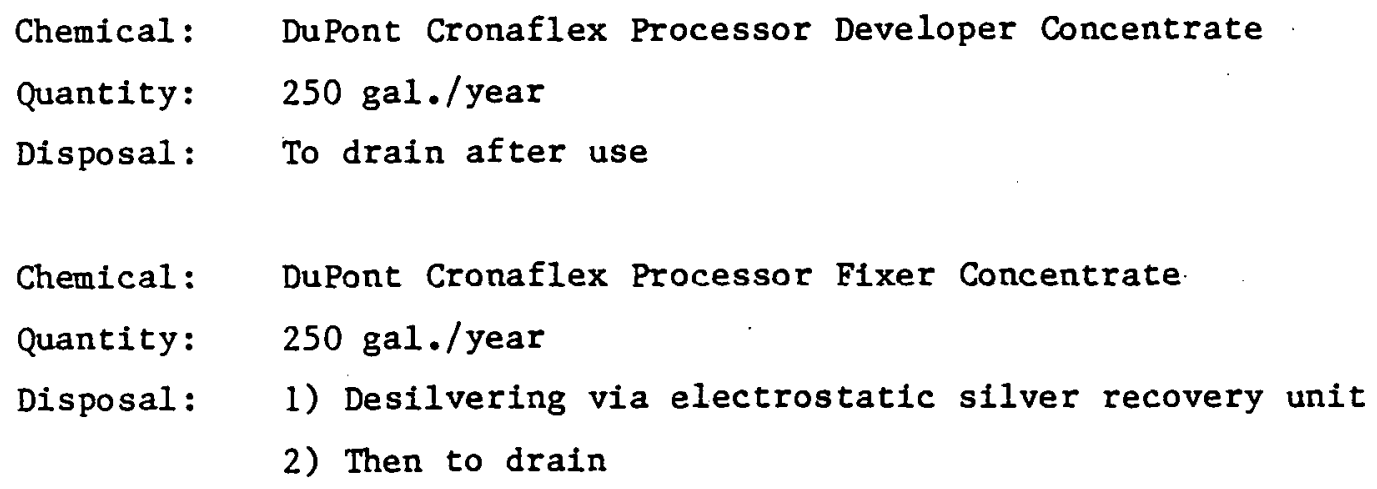

Chemical: Kodak Process E-6

1) First developer

2) Reversal bath

3) Color developer replenisher

4) Conditioner

5) Bleach

6) Fixer

7) Stabilizer

Quantity: 30 gal./year (projected)

Disposal: To drain after use

Chemical: Kodak Ektaflo Developer Type 1

Quantity: 15 gal./year

Disposal: To drain after use

Chemical: Kodak Indicator Stop Bath

Quantity: 4 gal./year

Disposal: To drain after use 
TABLE 7. PHOTOCHEMICALS PRESENTLY USED IN GRAND JUNCTION FACILITY PHOTOGRAPHIC LABORATORY (CONTINUED)

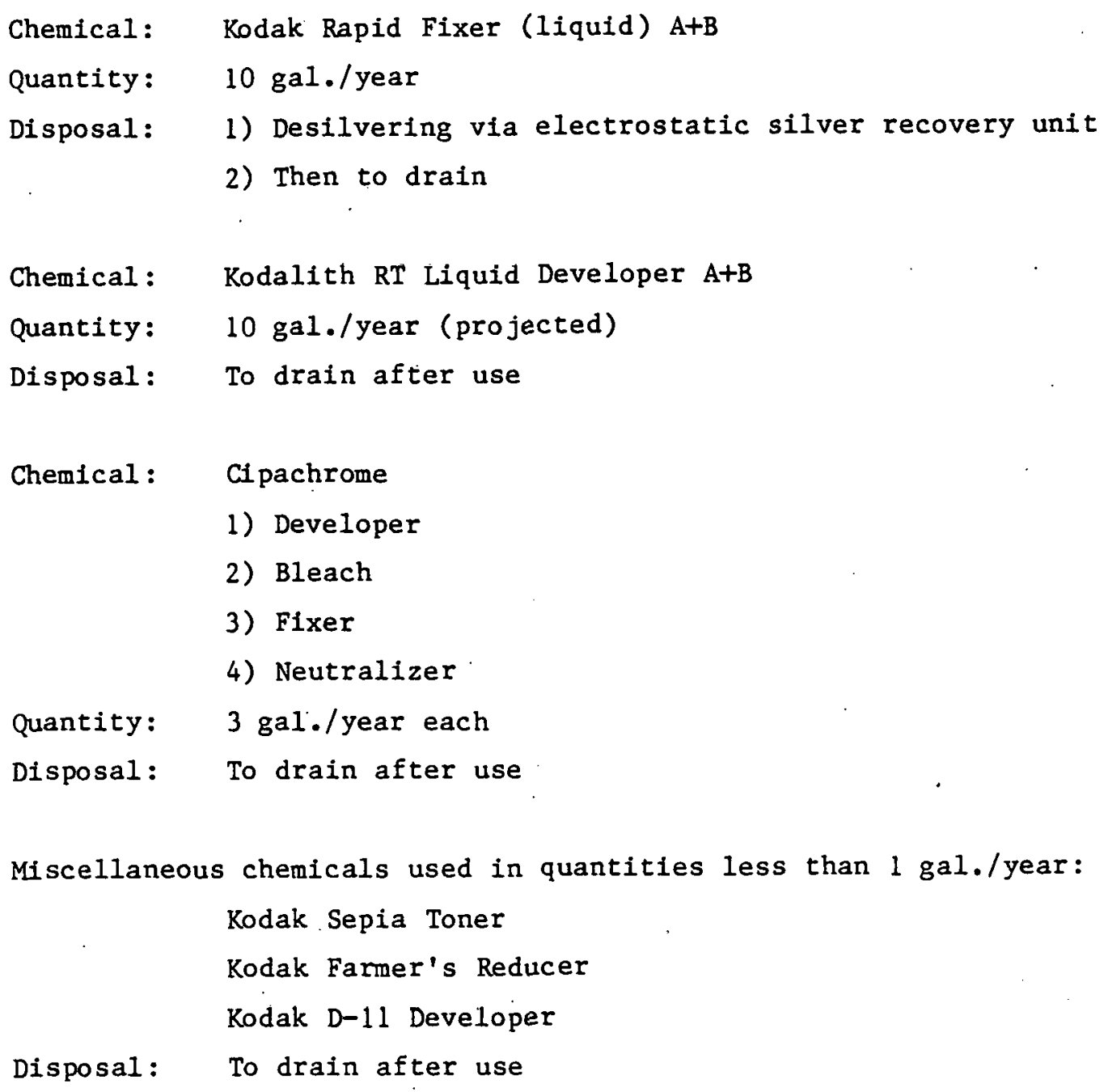


II. THE MONTICELLO, UTAH, INACTIVE URANIUM MILL SITE

\subsection{Site Environment}

\subsection{Facility Description and History}

The Department of Energy site at Monticello, Utah, was formerly a Governmentowned uranium processing mill. The mill operated for production of vanadium from 1941 to 1944; then taken over by the Atomic Energy Commission in 1948 and operated until January 1960 for the recovery of uranium. The site Includes approximately 900,000 tons of radioactive tafling impounded in four separate tallings ponds, covering an aggregate area of approximately 40 acres.

During the life of the Monticello Mill, several techniques for uranium recovery were practiced. Initial recovery was by roasting coupled with a carbonate leach. In November 1955, an ac1d leach resin-1n-pulp (RIP) process was initiated. The system was then reconverted to a carbonate process. The origin of the tailings is an important environmental consideration, since the various systems of uranium recovery tend to mobilize different materials.

Tailings dams were of the self-constructing variety, resulting in a dam composed of coarse sand, with fine slimes located in the middle of a pond area. The varlous types of resultant tailings material are shown on the facility map (Figure 2).

\subsection{Site Geology}

The Monticello site is underlain by the gently east dipping shales and sandstones of the Morrison and Dakota formations, with some Mancos shale outcrops. South Creek has cut a valley in the Morrison, Dakota, and Mancos which has subsequently been filled with alluvium and colluvium from slope wash. Permeability, and hence, movement of subsurface water is variable depending upon the 11thology. 


\subsection{Site Hydrology}

The hydrology of the Monticello site is greatly influenced by runoff from the Abajo Mountains to the west, down the channel of South Creek, and in the form of ground-water underflow in the geologic formations which outcrop to the west and dip toward the east.

The flow in South Creek is in two modes: spring runoff due to snow melt in the Abajo Mountains and intense but short-lived runoff events associated with . summer thunderstorms upon the mountain flanks. The former type of flow constitutes the major amount of runoff, but summer thunderstorms are important due. to their destructive erosional nature.

Most ground water pumped from the Monticello site is from deep wells penetrating sandstones of the Morrison or older geologic formations, such as the Entrada sañdstone. "Such water is frequently under artesian head due to the outcrop of the aquifers along the flank of the Abajo Mountains.

\subsection{Previous Environmental Degradation}

During and shortly after the operation of the Monticello site, there was significant environmental contamination in South Creek. This was documented by sampling conducted by the Atomic Energy Commission and the U.S. Public Health Service. Radium and uranium levels in South Creek were at or above allowable limits. There was also an indication of ground-water contamination in the area downgradient (east) of the site. This was most noted in the case of the "Sorensen" well, a shallow irrigation and stock water supply located approximately one mile east of the site. This contamination may have resulted from the subsurface movement of radium-bearing liquid waste from the tailings ponds through the alluvium along South Creek and into the well. Another possible source includes movement of dredged solids into the well. Other forms of environmental degradation included wind and water erosion of tailings into South creek and subsequent leaching of radionuclides. 


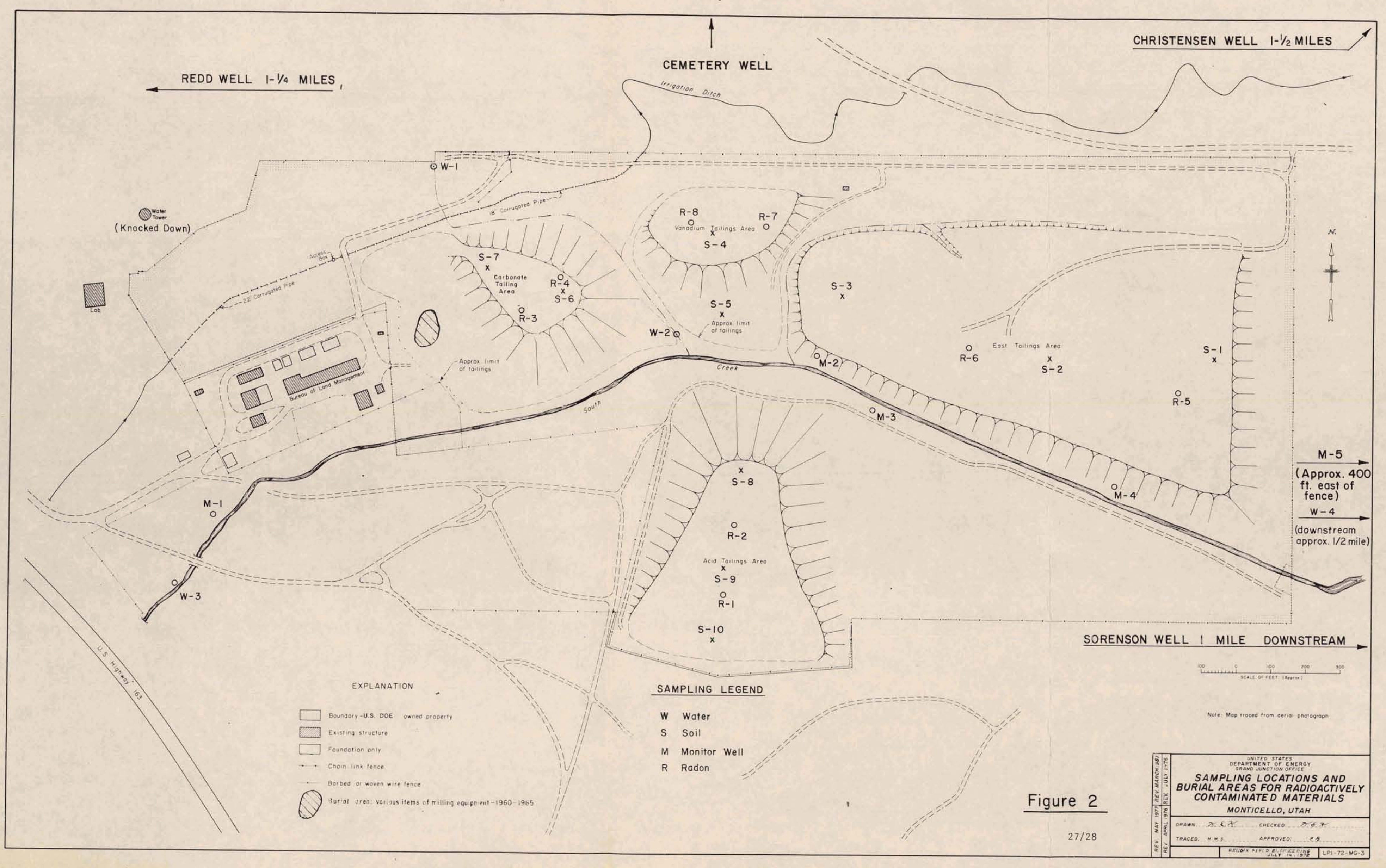




\subsection{Site Reclamation}

In an effort to control the environmental degradation resulting from the tailings pile, the U.S. Atomic Energy Commission conducted a site reclamation project at the Monticello facility beginning in August 1961. This action was a part of the Federal-State interagency pollution control effort on the Colorado River Basin. The restoration required 80 working days and an expenditure of $\$ 190,000$. Details of the project are contained in "A Report of the Monticello Mill Tailings Erosion Control Project, Monticello, Utah", prepared December 20, 1963, by the Grand Junction office of the U.S. Atomic Energy Commission. During the project, coarse sand tailings were added to the slime portions of the tailings ponds to form a firmer base. The pond surfaces were graded and leveled and 8-12 inches of pit-run rock and dirt plus topsoil were added to the surface, and the piles were seeded resulting in a reduction of gamma radiation of approximately one order of magnitude. Significant reductions in radium concentration within South Creek were also noted.

Subsequent to the tailings pile stabilization, the channel of South Creek was improved and riprapped to prevent erosion at the toe of the tailings piles.

\subsection{Existing Site Conditions}

While the efforts at site reclamation have done much to minimize the environmental effects of the Monticello facility, environmental degradation continues. There have been significant developments since the 1961 stabilization, which was originally intended only as an interim measure. Conditions causing continuing site degradation are discussed in the following section, abstracted from field notes taken during semi-annual inspections of the Monticello facility.

The diversion ditch along the north side of the Carbonate Pile downstream of sampling point $\mathrm{W}-1$ is in good shape and would be capable of carrying reasonably expected flows. Good vegetation cover is established on the soil covering the tailings area. There is no significant evidence of gullying or erosion, although there is some seepage on the southeast side of the pile. 
Vegetation coverage on the vanadium tailings pile is excellent. The drainage ditch along the north side is adequate. The ditch discharges through a culvert along the north side of the vanadium pile. A series of seeps have formed along the southeast side of the vanadium tailings pile. It appears that water could be entering the ground-water body surface seepage or spring water on the north side of the vanadium plle, moving through the pile, and surfacing on the southeast side of the pile.

The east tailings pile has good vegetative cover, including the cleanup from ore storage sites done during the 1974-1976 decontamination period.

There has been a significant amount of burrowing activity by small animals along the south side of the east tailings pile. This has resulted in the transport of talling sands to the surface for subsequent erosion by wind or water.

The acid tailings pile is located south of South Creek. The northwest side of the acid tailings pile is bounded by a small dike, which serves to channel runoff along the toe of the tallings pile. Vegetative cover on the acid tailings pile is well established.

A small holding pond is located on the east flank of the acid tailings pond. At the southwest corner of this pond is a large seep area, approximately 50 feet in diameter, which is extremely soft. This seep may be related to the former decant structure for the acid tallings pond, which may have been plugged and/or destroyed near the mouth, but which is still in existence within the pond area. This structure could serve as a ground-water drain for moisture moving through the tallings within the acid pile.

South Creek has been contained in a riprapped channel through the tailings ponds. No evidence of significant channel erosion was noted. The channel appears adequate for expected flows. 


\subsection{Current Environuental Status}

While the previous site reclamation efforts have done much to minimize environmental degradation from the Monticello facility, there are continuing environmental effects which should be considered in planning for ultimate site stabilization.

\subsection{Alr Quality Analyses}

The primary air concern associated with the Monticello factlity would be the continuing emanation of radon from the pile.

The existing piles are covered with approximately 8-12 inches of pit-run fill material, which offers some control over emanations of radon. Atmospheric pressure changes, erosion, and the burrowing of small rodents also affects the radon emanation.

Radon measurements were performed over a 1-year period in 1967 and 1968 and again in 1980. The 1967-1968 survey concluded that the tailings "do not significantly affect the environmental radon levels away from the tailings area". However, radon emanations from the Monticello facility are critical in view of the presence of human habitation within the town of Monticello to the north, and in the suburban area along South Creek to the east. Radon flux measurements were taken during the summer of 1980 , but the results have not been calculated because of calibration problems.

\subsection{Water Quality Analyses}

The water resources in the vicinity of the Monticello site were evaluated, based on three site inspections during. which water samples were taken, to determine possible contamination by toxic elements. 


\subsubsection{Surface Water}

Surface water contamination occurs as a result of sheet runoff directly from the piles or ground-water infiltration and subsequent appearance in surface streams.

Sample W-4 (Figure 2) is chosen to demonstrate off-site effects. The data taken during FY80 are shown in Table 8. These samples are clearly contaminated by the tailings. The elements arsenic, selenium, vanadium, molybdenum, and uranium are all present in elevated concentrations relative to the upstream sample $W-3$. Sample $W-2$, which was collected just east of the carbonate tailings, is heavily contaminated by these same elements. They are all mobile as oxyanions and undergo similar chemical reactions in natural systems. The low levels of radium are easily explained by the very high sulfate concentrations. Radium sulfate is very insoluble and the high sulfate concentration will cause it to be precipitated. Sediment samples would be expected to have a much higher radium-to-uranium ratio than the water.

Future analytical results will include all of the additional measurements suggested by EPA in "Environmental Protection Standards for Uranium Mill Tailings." The relevant standards are included in the table for ease of comparison. Molybdenum is the only element which exceeds the standards set by EPA. However, these standards are the same as the drinking water standards, and using those criteria, the vanadium concentration is ten times the allowable limit as well. It is also possible that arsenic levels exceed the standard at times of low flow.

\subsubsection{Ground Water}

During FY80 a series of wells were drilled to monitor the effects of the tallings on the ground water. Well M-1 is about 600 feet upstream from the tailings. Well $\mathrm{M}-2$ is located at the west side of the east tailings area alongside the creek. Wells $M-3$ and $M-4$ are approximately 200 feet and 600 feet further east, respectively. Well $M-5$ is approximately 100 feet east of 
TABLE 8. ANALYSES OF SURFACE WATER SAMPLES COLLECTED AT MONTICELLO DURING 1980

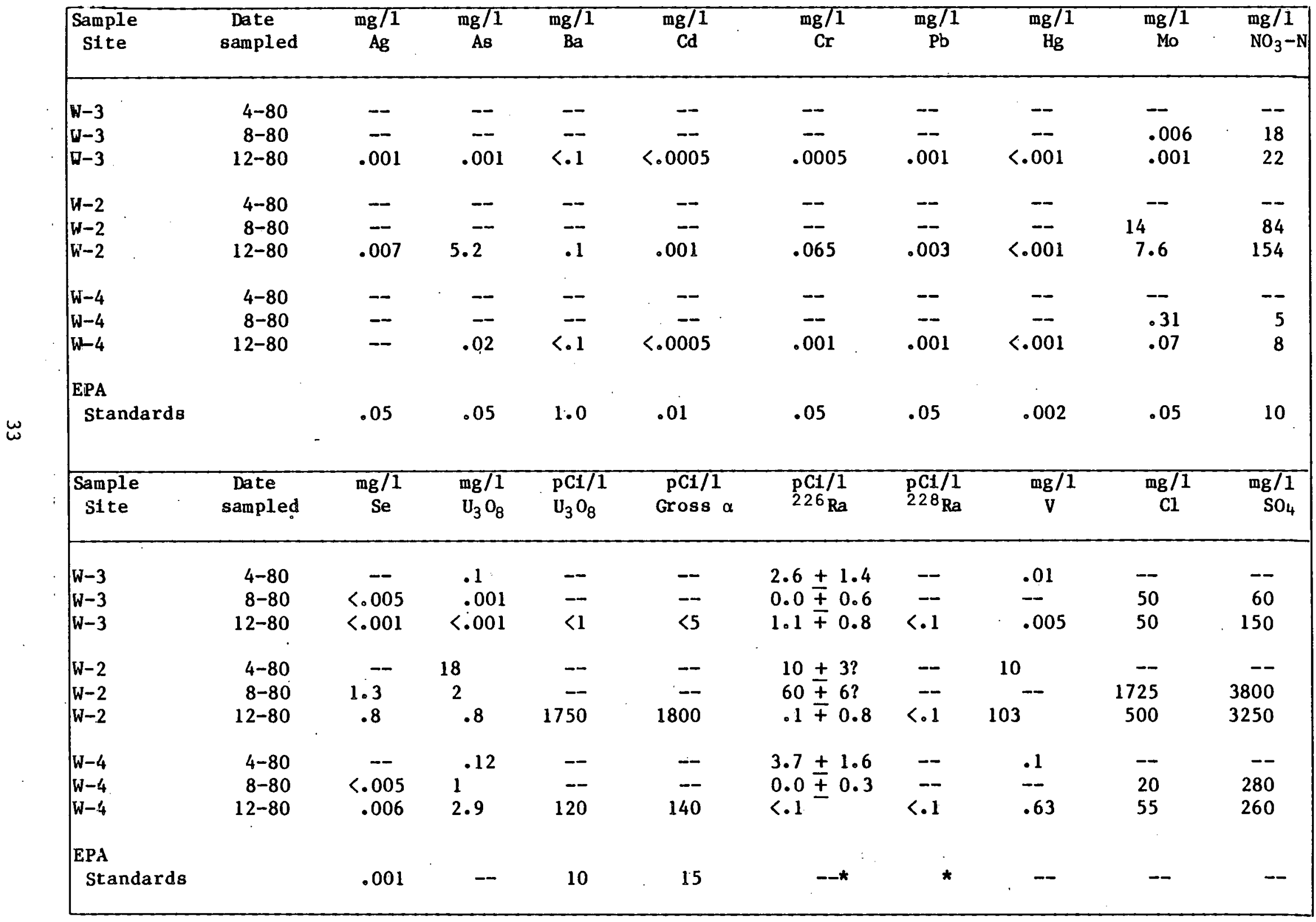

*Combined radium-226 and radium-228 $=5 \mathrm{pCl} / 1$ 
the tailings area. Ground-water flow is expected to be from west to east. Thus, M-1 should serve as a background location, and M-5 should show the off-site effect of the tallings.

Analytical data for samples from these wells are shown in Table 9. Significant contamination is evident in $M-2, M-3$, and $M-4$. The off-site sample, M-5, contains elevated levels of uranium, vanadium, chloride, sulfate, and molybdenum. There is quite a difference in the concentrations of these wells from fall to winter. Underground aquifers are not expected to show such variation in concentration over such a brief period. More data is required to fully explain this situation.

Samples were also collected during 1980 at the vicinity of the Sorensen well and three background wells located within 1-1/2 miles of the facility. These wells are shown on Figure 2 as the Redd Well, Christiansen Well, and Cemetery Well. These results are shown in Table 10 . The concentrations of all species measured on the background wells are conslderably lower than the Sorensen and M-5 wells indicating downstream contamination.

There are some inconsistencies in both the ground-water and surface-water data. Sampling and storage problems may account for some or all of this varlation. EPA specifications for collection and analysis of the samples will be used in FY81 and may eliminate this problem. On the other hand, elements such as uranium, vanadium, molybdenum, selenium, and arsenic (mobile as oxyanions) have clearly migrated from the tailings into adjacent water resources. There is a definite indication that applicable radiochemical and toxic element standards are being exceeded.

\subsection{Wind and Water Erosion}

Vegetative cover has become very well established on the pile surface, resulting in a reduction in wind and water erosion. However, the thin veneer of cover cannot be considered a permanent barrier for centuries. The piles are topographically high and will be attacked by erosional forces, which ultimately would lead to breaching and movement of the tallings into the environment unless the maintenance program is continued and improved. Ninety cubic yards of topsoil were added to eroded areas during 1980. 
TABLE 9. ANALySES OF WELl WATER SAMPLES COLLECTED AT THE MONTICELLO SITE DURING 1980

\begin{tabular}{|c|c|c|c|c|c|c|c|c|c|c|}
\hline $\begin{array}{l}\text { We11 } \\
\text { Site }\end{array}$ & $\begin{array}{c}\text { Date } \\
\text { sampled }\end{array}$ & $\begin{array}{c}\mathrm{mg} / 1 \\
\mathrm{Ag}\end{array}$ & $\begin{array}{c}\mathrm{mg} / 1 \\
\text { As }\end{array}$ & $\begin{array}{c}\mathrm{mg} / 1 \\
\mathrm{Ba}\end{array}$ & $\begin{array}{c}\mathrm{mg} / 1 \\
\mathrm{Cd}\end{array}$ & $\begin{array}{c}\mathrm{mg} / 1 \\
\mathrm{Cr}\end{array}$ & $\underset{\mathrm{Pb}}{\mathrm{mg} / 1}$ & $\begin{array}{c}\mathrm{mg} / 1 \\
\mathrm{Hg}\end{array}$ & $\begin{array}{c}\mathrm{mg} / 1 \\
\text { Mo }\end{array}$ & $\begin{array}{l}\mathrm{mg} / 1 \\
\mathrm{NO}_{\mathfrak{j}}-\mathrm{N}\end{array}$ \\
\hline$M-1$ & $4-80$ & - & - & - & - & -- & - & - & -- & - \\
\hline$M-1$ & $8-80$ & - & -- & -- & -- & -- & - & - & .011 & 2 \\
\hline$M-1$ & $12-80$ & $<.0005$ & .008 & .1 & .0005 & .001 & .002 & $<.001$ & .007 & 4 \\
\hline$M-2$ & $4-80$ & - & - & - & -- & - & - & -- & -- & -- \\
\hline$M-2$ & $8-80$ & -- & - & -- & -- & - & -- & -- & .085 & 7 \\
\hline$M-2$ & $12-80$ & .002 & .075 & .2 & .0005 & .01 & $<.001$ & $<.001$ & .03 & $<1$ \\
\hline$M-3$ & $4-80$ & - & -- & - & -- & - & - & - & - & -- \\
\hline$M-3$ & $8-80$ & - & -- & -- & - & - & - & -- & .02 & 930 \\
\hline$M-3$ & $12-80$ & .006 & .04 & .1 & .001 & .04 & $<.001$ & $<.001$ & .04 & 520 \\
\hline$M-4$ & $4-80$ & -- & - & - & -- & - & - & -- & -- & - \\
\hline$M-4$ & $8-80$ & -- & - & -- & -- & - & -- & -- & .1 & 7 \\
\hline$M-4$ & $12-80$ & .002 & .02 & $<.1$ & $<.005$ & .003 & $<.001$ & $<.001$ & 1.2 & 6 \\
\hline$M-5$ & $4-80$ & -- & - & -- & - & - & -- & -- & - & -- \\
\hline$x-5$ & $8-80$ & - & -- & -- & -- & -- & - & -- & .13 & 2 \\
\hline$M-5$ & $12-80$ & .0005 & .006 & .1 & .001 & .001 & $<.001$ & $<.001$ & .08 & $<1$ \\
\hline \multicolumn{11}{|l|}{ EPA } \\
\hline Standards & & .05 & .05 & 1.0 & .01 & .05 & .05 & .002 & .05 & 10 \\
\hline
\end{tabular}


TABLE 9. ANALYSES OF WELl WATER SAMPLES COLLECTED AT THE MONTICELlO SITE DURING 1980 (CONTINUED)

\begin{tabular}{|c|c|c|c|c|c|c|c|c|c|c|}
\hline $\begin{array}{l}\text { Well } \\
\text { Site }\end{array}$ & $\begin{array}{c}\text { Date } \\
\text { sampled }\end{array}$ & $\begin{array}{c}\mathrm{mg} / 1 \\
\mathrm{Se}\end{array}$ & $\begin{array}{l}\mathrm{mg} / 1 \\
\mathrm{U}_{3} \mathrm{O}_{8}\end{array}$ & $\begin{array}{l}\mathrm{pCi} / 1 \\
\mathrm{U}_{3} \mathrm{O}_{8}\end{array}$ & $\begin{array}{c}\mathrm{pC1} / 1 \\
\text { Gross } \alpha\end{array}$ & ${ }_{226}^{\mathrm{pCl} / 1} \mathrm{Ra}$ & $\begin{array}{l}\mathrm{pCl} / 1 \\
{ }_{228} \mathrm{Ra}\end{array}$ & $\underset{\mathrm{V}}{\mathrm{mg} / 1}$ & $\underset{\mathrm{Cl}}{\mathrm{mg} / 1}$ & $\begin{array}{r}\mathrm{mg} / 1 \\
\mathrm{SO}_{4}\end{array}$ \\
\hline $\begin{array}{l}M-1 \\
M-1 \\
M-1\end{array}$ & $\begin{array}{r}4-80 \\
8-80 \\
12-80\end{array}$ & $\begin{array}{l}-\overline{-} \\
<.005 \\
.002\end{array}$ & $\begin{array}{l}.25 \\
.05 \\
.1\end{array}$ & $\begin{array}{l}-- \\
\overline{50}\end{array}$ & $\overline{--}$ & $\begin{array}{l}2.7 \pm 1.3 \\
1.1 \pm 1.0 \\
2.3 \pm 0.8\end{array}$ & $\begin{array}{l}\overline{-} \\
\overline{c .1}\end{array}$ & $\begin{array}{l}.01 \\
.009 \\
.06\end{array}$ & $\begin{array}{c}-- \\
7 \\
20\end{array}$ & $\begin{array}{r}-- \\
125 \\
85\end{array}$ \\
\hline $\begin{array}{l}M-2 \\
M-2 \\
M-2\end{array}$ & $\begin{array}{r}4-80 \\
8-80 \\
12-80\end{array}$ & $\begin{array}{r}--- \\
<.005 \\
.003\end{array}$ & $\begin{array}{l}20 \\
39 \\
1.1\end{array}$ & $\begin{array}{r}-- \\
\overline{--} \\
1920\end{array}$ & $\begin{array}{r}-- \\
1930\end{array}$ & $\begin{array}{l}9.2 \pm 2.7 \\
15 \pm 4 \\
5.4 \pm 0.8\end{array}$ & $\overline{--}$ & $\begin{array}{l}.11 \\
.2 \\
.08\end{array}$ & $\begin{array}{r}-- \\
15 \\
190\end{array}$ & $\begin{array}{r}-- \\
857 \\
570\end{array}$ \\
\hline $\begin{array}{l}M-3 \\
M-3 \\
M-3\end{array}$ & $\begin{array}{r}4-80 \\
8-80 \\
12-80\end{array}$ & $\begin{array}{l}-- \\
.07 \\
.1\end{array}$ & $\begin{array}{l}1.7 \\
4 \\
2.2\end{array}$ & $\begin{array}{r}-- \\
\overline{--} \\
1360\end{array}$ & $\begin{array}{r}-- \\
1320\end{array}$ & $\begin{array}{r}1.9 \pm 1.1 \\
1.3 \pm 0.9 \\
.9 \pm 0.8\end{array}$ & $\overline{-}$ & $\begin{array}{l}.05 \\
.07 \\
.16\end{array}$ & $\begin{array}{l}-\overline{80} \\
58\end{array}$ & $\begin{array}{r}-- \\
3250 \\
3860\end{array}$ \\
\hline $\begin{array}{l}M-4 \\
M-4 \\
M-4\end{array}$ & $\begin{array}{r}4-80 \\
8-80 \\
12-80\end{array}$ & $\begin{array}{l}-\overline{-} \\
.005 \\
.003\end{array}$ & $\begin{array}{l}12 \\
2 \\
4.7\end{array}$ & $\begin{array}{r}-- \\
2770\end{array}$ & $\begin{array}{r}-- \\
2500\end{array}$ & $\begin{array}{l}3.9 \pm 1.8 \\
1.9 \pm 1.1 \\
3.3 \pm 0.8\end{array}$ & $\overline{--}$ & $\begin{array}{l}.02 \\
.01 \\
.007\end{array}$ & $\begin{array}{l}-\overline{16} \\
20\end{array}$ & $\begin{array}{r}-- \\
880 \\
720\end{array}$ \\
\hline $\begin{array}{l}M-5 \\
M-5 \\
M-5\end{array}$ & $\begin{array}{r}4-80 \\
8-80 \\
12-80\end{array}$ & $\begin{array}{r}-\overline{-} \\
<.005 \\
.002\end{array}$ & $6^{.54}$ & $\overline{--}$ & $\overline{--}$ & $\begin{array}{l}1.5 \pm 1.0 \\
1.1 \pm 1.0 \\
2.1 \pm 0.8\end{array}$ & $\begin{array}{l}-- \\
\overline{--} \\
<.1\end{array}$ & $\begin{array}{r}.04 \\
.12 \\
40\end{array}$ & $\begin{array}{r}\overline{70} \\
100\end{array}$ & $\begin{array}{l}-\overline{420} \\
390\end{array}$ \\
\hline $\begin{array}{l}\text { EPA } \\
\text { Standards }\end{array}$ & & .01 & -- & 10 & 15 & * & * & -- & -- & -- \\
\hline
\end{tabular}

* Combined radium-226 and radium-228 - $5 \mathrm{pCi} / 1$ 
TABLE 10. ANALYSES OF OFF -SITE WELL WATER SAMPLES COLLECTED NEAR THE MONTICELLO SITE DURING 1980

\begin{tabular}{|c|c|c|c|c|c|c|c|c|c|c|}
\hline $\begin{array}{l}\text { Sample** } \\
\text { site }\end{array}$ & $\begin{array}{c}\text { Date } \\
\text { sampled }\end{array}$ & $\begin{array}{c}\mathrm{mg} / 1 \\
\mathrm{Ag}\end{array}$ & $\begin{array}{c}\mathrm{mg} / 1 \\
\text { As }\end{array}$ & $\begin{array}{c}\mathrm{mg} / 1 \\
\mathrm{Ba}\end{array}$ & $\begin{array}{c}\mathrm{mg} / 1 \\
\mathrm{Cd}\end{array}$ & $\begin{array}{c}\mathrm{mg} / 1 \\
\mathrm{Cr}\end{array}$ & $\begin{array}{c}\mathrm{mg} / 1 \\
\mathrm{~Pb}\end{array}$ & $\begin{array}{c}\mathrm{mg} / 1 \\
\mathrm{Hg}\end{array}$ & $\begin{array}{c}\mathrm{mg} / 1 \\
\text { Mo }\end{array}$ & $\begin{array}{l}\mathrm{mg} / 1 \\
\mathrm{NO}_{3}-\mathrm{N}\end{array}$ \\
\hline Christensen & $8-80$ & -- & - & - & -- & - & - & $\therefore \quad--$ & $<.005$ & $<1$ \\
\hline Redd & $8-80$ & -- & -- & -- & -- & -- & - & -- & .007 & $<1$ \\
\hline Cemetery & $8-80$ & -- & -- & - & -- & -- & -- & - & $<.005$ & $<1$ \\
\hline Sorenson & $12-80$ & $<.005$ & .012 & $<.1$ & .001 & $<.0005$ & .002 & $<.001$ & .06 & 6 \\
\hline \multicolumn{11}{|l|}{ EPA } \\
\hline Standards & & .05 & .05 & 1.0 & .01 & .05 & .05 & .002 & .05 & 10 \\
\hline $\begin{array}{l}\text { Sample**} \\
\text { Site }\end{array}$ & $\begin{array}{c}\text { Date } \\
\text { Sampled }\end{array}$ & $\begin{array}{l}\mathrm{mg} / 1 \\
\mathrm{Se}\end{array}$ & $\begin{array}{l}\mathrm{mg} / 1 \\
\mathrm{U}_{3} \mathrm{O}_{8}\end{array}$ & $\begin{array}{l}\mathrm{pC1/1} \\
\mathrm{U}_{3} \mathrm{O}_{8}\end{array}$ & $\begin{array}{c}\mathrm{pCi} / 1 \\
\text { Gross } \alpha\end{array}$ & $\begin{array}{l}\mathrm{p}_{21 / 1}^{\mathrm{Cl} / 1} \\
26_{\mathrm{Ra}}\end{array}$ & $\begin{array}{l}\mathrm{pC} 1 / 1 \\
228_{\mathrm{Ra}}\end{array}$ & $\underset{\mathrm{Vg}}{\mathrm{mg} / 1}$ & $\begin{array}{c}\mathrm{mg} / 1 \\
\mathrm{Cl}\end{array}$ & $\begin{array}{r}\mathrm{mg} / 1 \\
\mathrm{SO}_{4}\end{array}$ \\
\hline Redd & $8-80$ & $<.005$ & .002 & - & -- & $0.2 \pm 0.4$ & - & .03 & 6 & 650 \\
\hline Cemetery & $8-80$ & $<.005$ & .002 & & & $0.8 \pm 0.7$ & & $<.005$ & 2 & 60 \\
\hline Sorenson & $8-80$ & .009 & .67 & -- & -- & $0.0 \pm 0.5$ & - & .33 & 30 & 300 \\
\hline Sorenson & $12-80$ & $<.001$ & .35 & 210 & 150 & 1.3 & $<.1$ & .13 & 60 & 435 \\
\hline \multicolumn{11}{|l|}{ EPA } \\
\hline Standards & & .01 & -- & 10 & 15 & * & * & -- & -- & -- \\
\hline
\end{tabular}

**0n1y the Sorenson well might be contaminated by the Monticello facility. The other wells are background samples.

*Combined radium-226 and radium-228 $=5 \mathrm{pCi} / 1$ 


\subsection{Improvement Programs}

Final decontamination and decommissioning of the Monticello site has been authorized as part of the DOE Surplus Facilities Management Program. Detailed environmental and engineering studies will be initiated during FY 1982. If the tailings must be relocated to a more environmentally suitable location, it is estimated the project will be completed in 1992. 
